\begin{tabular}{c|c|c} 
Submission: & Article History & Accepted: \\
08-07-2019 & Review: & Ac-072019 \\
29-07-2019
\end{tabular}

\title{
Pembentukan Karakter Religius Siswa Melalui Kegiatan Dewan Jamaah Mushola (DJM) Di SMK PGRI 2 Kota Kediri
}

\author{
Defi Sulistiyorini ${ }^{1}$, Yasin Nurfalah ${ }^{2}$ \\ ${ }^{1}$ Institut Agama Islam Tribakti Kediri, ${ }^{2}$ Institut Agama Islam Tribakti Kediri \\ 11defisulistiyo@gmail.com, 2yesnurfalah@gmail.com@gmail.com
}

\begin{abstract}
The religious character on the Aqeedah dimension, dimensions of worship, and moral dimensions through the activities of the Jamaah Mushola Council (DJM) at SMK PGRI 2, Kediri City. This study used a descriptive qualitative method of describing how the religious character of SMK PGRI 2 Kediri was formed through the activities of the DJM. The data analysis technique uses Milles and Haberman models. The results of the first study of the religious character in the Islamic dimension activities are Islamic law discourse and the recitation of the book Mabadi 'Al-fiqhiyyah. Second, the activities of forming the characters of worship in congregation, diba'iyyah, the art of reading the Koran, and the Koran. And thirdly, the formation of the religious character in the moral dimension by using the habituation method that has a noble character, which is done by familiarizing students with attitude to anyone and wherever they are.
\end{abstract}

Keywords: Religious Character, Activities of the Mushola Jamaat Council

\begin{abstract}
Abstrak
Penelitian ini bertujuan untuk mengetahui pembentukan karakter religius siswa pada dimensi Aqidah, dimensi ibadah, dan dimensi akhlak melalui kegiatan Dewan Jamaah Mushola (DJM) di SMK PGRI 2 Kota Kediri. Penelitian ini menggunakan metode kualitatif deskriptif dengan tujuan untuk mendeskripsikan bagaimana pembentukan karakter religious SMK PGRI 2 Kota Kediri melalui kegiatan DJM. Teknik analisis data dalam penelitian ini menggunakan model Milles dan Haberman. Hasil penelitian mengungkapkan bahwa, pertama, pembentukan karakter religius pada dimensi Aqidah ini melalui kegiatan kajian islam yang materinya membahas tentang hukumhukum Islam, dan kegiatan pengajian kitab Mabadi' Al-fiqhiyyah. Kedua, kegiatan pembentukan karakter religius pada dimensi ibadah yaitu melalui kegiatan pembiasaan shalat dhuhur berjamaah, diba'iyyah, seni baca Al-Quran, dan khotmil Quran. Dan ketiga, Pembentukan karakter religius pada dimensi akhlak yaitu dengan menggunakan metode pembiasaan berakhlak terpuji, yang dilakukan dengan membiasakan siswa untuk bersikap tawadhu' kepada siapapun dan dimanapun mereka berada.
\end{abstract}

Kata Kunci: Karakter Religius, Kegiatan Dewan Jamaah Mushola 


\section{Pendahuluan}

Pendidikan karakter menjadi isu penting dalam dunia pendidikan, hal ini berkaitan dengan fenomena dekadensi moral yang tengah terjadi dilingkungan pemerintah dan ditengah-tengah masyarakat. Tindakan kriminalitas, asusila, dan tindakan korupsi, menjadi bukti nyata telah terjadi krisis jatidiri dan karakteristik pada bangsa Indonesia. Budi pekerti luhur, sopan santun, dan nilai agama yang dijunjung tinggi dan menjadi budaya masyarakat Indonesia saat ini seakan menjadi terasa asing dan jarang ditemui ditengah masyarakat. Pendidikan karakter menjadi sebuah jawaban yang tepat atas permasalahan yang tengah dihadapi bangsa, dan sekolah sebagai penyelenggara pendidikan diharapkan dapat menjadi wadah yang mampu mewujudkan tujuan dari pendidikan karakter.

Pendidikan merupakan pengalaman belajar terprogram dalam membentuk pendidikan formal maupun non formal, pendidikan disekolah dan luar sekolah yang bertujuan untuk memaksimalkan kemampuan individu agar dapat hidup baik ditengah masyarakat. Dalam meningkatkan kualitas pendidikan yang memiliki nilai-nilai keagamaan, maka memerlukan proses pembelajaran tentang materi keagamaan melalui pembelajaran.

Karakter merupakan nilai perilaku manusia yang berhubungan dengan Tuhan Yang Maha Esa, sesama manusia, lingkungan, dan kebangsaan. Karakter dimaknai sebagai perilaku yang tampak dalam kehidupan sehari-hari dalam bersikap maupun bertindak dalam melakukan sesuatu. ${ }^{1}$ Menurut Zubaedi karakter mempunyai empat sumber yaitu agama, pancasila, budaya, dan tujuan pendidikan indonesia. Keempat sumber tersebut memuat nilai-nilai kemanusiaan yang harus dimiliki oleh bangsa indonesia. Nilai karakter religius berisi tentang sikap dan perilaku yang patuh dalam melaksanakan ajaran agama yang dianutnya, serta toleran terhadap agama lain. ${ }^{2}$

Untuk mengembangkan karakter peserta didik memerlukan kegiatan tambahan diluar jam pelajaran yang dapat menunjang pengembangan karakter peserta didik. Salah satu wadah pengembangan karakter peserta didik disekolah adalah melalui kegiatan ekstrakulikuler. Kegiatan ekstrakulikuler merupakan kegiatan yang diselenggarakan diluar jam pelajaran wajib untuk memperluas pengetahuan siswa khususnya dalam

\footnotetext{
${ }^{1}$ Muchlas Samani dan Hariyanto, Konsep dan Model Pendidikan Karakter (Bandung: PT Remaja Rosdakarya, 2011), h.41.

${ }^{2}$ Zubaedi, Desain Pendidikan Karakter (Jakarta:Kencana, 2013), h.73. 
pembentukan karakter siswa yang berakhlak baik. Dalam kegiatan ekstrakulikuler terdapat kegiatan yang bersifat keagamaan yang bertujuan membentuk intelektual dan jiwa dalam diri siswa dengan menanamkan nilai keagamaan disetiap kegiatannya.

Kegiatan ekstrakulikuler keagamaan merupakan kegiatan yang diselenggarakan dalam rangka memberikan arahan kepada siswa untuk mengamalkan ajaran agama yang diperolehnya, serta mendorong siswa membentuk karakter siswa sesuai dengan nilai nilai agama. Tujuannya adalah membentuk manusia yang mempunyi ilmu pengetahuan, siswa juga diharapkan menjadi manusia yang menjalankan perintah agama dan menjauhi larangannya. ${ }^{3}$ Pendidikan pembentukan karakter merupakan upaya untuk menumbuhkan perilaku positif pada diri anak, sehingga anak berperilaku sesuai dengan yang diharapkan. $^{4}$

Dalam hal ini penulis melakukan penelitian di SMK PGRI 2 Kota Kediri melaui kegiatan ekstrakulikuler Dewan Jamaah Mushola (DJM). Kegiatan DJM ini banyak di minati oleh siswa-siswi SMK PGRI 2 khususnya yang beragama islam. Kegiatan yang ada di dalam DJM bermacam-macam diantaranya adalah; diba'iyyah, pengajian kitab kuning, khotmil Quran, seni baca al-qur'an, kajian dialog Islam.

Pembentukan karakter religius di SMK PGRI 2 Kota Kediri melalui kegiatan Dewan Jamaah Mushola (DJM) ini menanamkan nilai-nilai yang baik dan bersumber dari ajaran islam pada siswanya melalui pemahaman, pembiasaan, dan peneladanan. Jadi apa yang sudah diperoleh siswa saat pembelajaran akan diaplikasikan dalam kegiatan keagamaan, sehingga lambat laun akan muncul karakter religius dalam diri siswa. Berdasarkan keunikan program yang disebutkan diatas maka peneliti tertarik untuk meneliti dan melakukan observasi di SMK PGRI 2 Kota Kediri.

\section{Metode Penelitian}

Penelitian ini dilakukan di SMK PGRI 2 Kota Kediri yang terletak di Jalan KH. Abdul Karim (Jl. Ponpes Lirboyo) No. 5 Kediri. Penelitian ini adalah untuk mengetahui proses pembentukan karakter religius melalui kegiatan Dewan Jama'ah Musholla siswa SMK PGRI 2 Kota Kediri. Sebagai upaya untuk mengetahui proses pembentukan karakter religius siswa, maka dengan ini penulis menggunakan pendekatan kualitatif. Ditinjau dari data yang diperoleh penulis, penelitian ini digolongkan pada jenis penelitian

\footnotetext{
${ }^{3}$ Departemen Agama RI, Panduan Kegiatan Ekstrakulikuler Pendidikan Agama Islam (Jakarta: Direktorat Jenderal Kelembagaan Pendidikan Agama Islam,2005), h.9. 2014), h.9

${ }^{4}$ Deni Damayanti, Panduan Implementasi Pendidikan Karakter di Sekolah, (Jogjakarta: Araska,
} 
lapangan kulitatif dengan jenis studi kasus. Oleh karena itu peneliti menggunakan wawancara mendalam dan sebagai langkah pengumpulan data, penelitian ini dilakukan dengan cara mencari data secara langsung dilapangan serta mempelajari individu secara rinci dan mendalam selama kurun waktu tertentu untuk membantunya memperoleh penyesuaian diri yang lebih baik, dan penelitian ini digunakan untuk memahami fenomena yang dialami oleh anggota Dewan Jamaah Mushola (DJM) di SMK PGRI 2 Kota Kediri yang dideskripsikan dan dirumuskan menjadi model, konsep, teori, dan definisi secara umum.

\section{Pembahasan}

Sesuai dengan pengamatan yang dilakukan, dalam membentuk karakter religius siswa merupakan hal yang menjadi tujuan utama khususnya bagi guru PAI pada sekolah umum. Salah satu upaya untuk membentuk karakter religius siswa yaitu melalui kegiatan ekstrakulikuler Dewan Jamaah Mushola. Kegiatan ekstrakulikuler ini merupakan upaya dari sekolah sebagai sebuah proses dalam membentuk manusia muslim dalam merealisasikan tugas dan fungsinya sebagai khalifah dimuka bumi. ${ }^{5}$

Kegiatan ekstrakulikuler Dewan Jamaah Mushola (DJM) merupakan kegiatan yang dilakukan diluar jam pelajaran yang telah ditentukan berdasarkan kebijakan sekolah. Kegiatan ini dimaksudkan untuk meningkatkan wawasan dan kemampuan yang diperoleh siswa. Atas dasar inilah, maka sekolah mengembangkan potensi yang dimiliki oleh peserta didik khususnya yang beragama islam. Pembentukan yang dilakukan melalui kegiatan Dewan Jamaah Mushola ini mempunyai tiga pokok ajaran agama Islam yaitu pada dimensi aqidah, dimensi ibadah, dan dimensi akhlak.

Dewan Jamaah Mushola ini bertujuan untuk membentuk siswa untuk memperdalam agama sesuai dengan ajaran agama islam. Pembentukan ini dilakukan melalui metode pembiasaan yang dilakukan oleh pembimbing. Dengan metode pembiasaan ini diharapkan agar karakter religius dapat melekat dalam diri siswa. ${ }^{6}$

Bentuk kegiatan keagamaan Dewan Jamaah Mushola (DJM) yang dilakukan setiap hari Jumat dan sabtu di SMK PGRI 2 Kota Kediri ini meliputi; Seni baca tulis Al-Quran (Jumat Pahing), Kajian dan Dialog Keislaman (Jumat Pon), Pengajian kitab kuning (Jumat Wage), Khotmil Quran (Jumat Kliwon), dan Maulid Diba'iyah dan Khitobah

\footnotetext{
${ }^{5}$ Lisa'diyah Ma'rifataini, "Model Penanaman Nilai-Nilai Karakter Siswa SMA Berbasis Pendidikan Agama”, Jurnal Penelitian Pendidikan Agama dan Keagamaan, Vol 13. 1 (April 2015), h.82.

${ }^{6}$ Siswanto, "Pendidikan Karakter Berbasis Nilai-Nilai Religius", Jurnal Pendidikan Islam, Vol.8, 1 (Juni 2013), h.101.
} 
(Jumat Legi). Semantara bentuk kegiatan Dewan Jamaah Mushola (DJM) program bulanan dan tahunan meliputi; Peringatan Hari Besar Islam (PHBI) yang di dalamnya mencakup kegiatan Maulid Nabi Muhammad SAW, Rojabiyah, Idhul Adha, Peringatan 1 Muharom, Pondok Ramadhan, Ziarah Makam Auliya' / Bulan Sya'ban.

Dalam proses pembentukan karakter siswa melalui kegiatan ekstrakurikuler ini didampingi oleh guru PAI sebagai pembimbing. Guru harus mempunyai pemahaman dan kemampuan dalam menerapkan berbagai model, metode, teknik, pendekatan, dan strategi dalam menyampaikan nilai-nilai religius yang ada untuk membentuk karakter keagamaan peserta didik. ${ }^{7}$ Dengan adanya pengawasan dari guru diharapkan kegiatan ini mampu membentuk karakter religius siswa sesuai visi misi DJM yang telah ditentukan yaitu mencetak generasi muda yang berpegang teguh pada Al-Qur'an dan hadist serta Menanamkan ajaran islam pada generasi muda dalam bidang aqidah, ibadah, akhlak, dan muamalah.

\section{Pembentukan Karakter Religius Siswa pada Dimensi Aqidah Melalui Kegiatan Dewan Jamaah Mushola (DJM) di SMK PGRI 2 Kota Kediri.}

Berdasarkan pengamatan yang dilakukan oleh peneliti, bahwa kegiatan ekstrakulikuler adalah salah satu cara dalam membentuk karakter religius siswa. Karakter religius sama dengan ajaran pokok Islam. Salah satu ajaran pokoknya yaitu pada dimensi aqidah.

Menurut Muhammad Daud Ali Aqidah secara etimologi adalah ikatan, sedangan secara terminologi aqidah adalah iman, keyakinan yang ditautkan dengan rukun iman yang merupakan asas seluruh ajaran Islam. ${ }^{8}$ Pembentukan karakter religius pada dimensi aqidah pada kegiatan Dewan Jamaah Mushola salah satunya yaitu pada kegiatan kajian Islam. Kajian berasal dari kata "kaji" yang menurut KBBI adalah meneliti atau mempelajari tentang ilmu-ilmu agama Islam. ${ }^{9}$ Sedangkan Islam menurut Mohammad Ali Daud berasal dari kata "salama" yang artinya patuh atau menerima, kata dasar salama yaitu sejahtera, dari kata -kata tersebut terbentuk kata masdar yaitu salamat. Sehingga dapat disimpulkan Islam adalah kedamaian, kesejahteraan, keselamatan, penyerahan diri, dan ketaatan. ${ }^{10}$

\footnotetext{
${ }^{7}$ Arnani Faiziyah,'Transformasi Nilai-Nilai Religius Dalam Pembentukan Karakter (Studi Kasus Pada Siswa SMK Arrahmah Purwotengah Papar Kediri)", Jurnal Pendidikan Islam, Vol.7. 1 (Desember 2017), h.18.

${ }^{8}$ Mohammad Ali Daud, Pendidikan Agama Islam (Jakarta: Raja Grafindo Persada, 1998), h.133.

${ }^{9}$ Tim Penyususn Kamus Pusat Pembinaan dan Pengembangan Bahasa Departemen Pendidikan dan Kebudayaan, Kamus Besar Bahasa Indonesia (Jakarta: Balai Pustaka, 1994), h.431.

${ }^{10}$ Mohammad Ali Daud, Pendidikan Agama Islam., h.49.
} 
Sesuai dengan pendapat di atas kajian Islam adalah meneliti atau mempelajari ilmuilmu tentang agama Islam yang dapat memberikan kedamaian dan kesejahteraan baik untuk diri sendiri maupun untuk orang lain. Khoiron Rosyadi menyatakan bahwa Kajian Islam ditujukan untuk mencapai keseimbangan pertumbuhan diri pribadi manusia secara menyeluruh melalui latihan kejiwaan, akal, pikiran, kecerdasan, perasaan, dan panca indra. Oleh karena itu, kajian Islam mengembangkan seluruh aspek kehidupan manusia, baik spiritual, intelektual, imajinasi, jasmaniah, ataupun rohaniah baik secara individu maupun kelompok serta mendorong aspek-aspek ke arah kebaikan dan pencapaian kesempurnaan hidup. ${ }^{11}$

Dari penjelasan tersebut dapat disimpulkan bahwa kajian Islam bertujuan untuk melatih pribadi manusia menjadi lebih baik dihadapan Allah dan manusia melalui pembiasaan atau latihan-latihan untuk mengembangkan sikap kerohanian dan aqidah dalam diri manusia tersebut.

Dalam lingkungan sekolah umum kajian Islam dilakukan menggunakan metode agar pada saat mengajarkan pada siswa tidak menjadi bosan. Kajian Islam ini menggunakan dua metode yaitu dengan ceramah dan tanya jawab. Pada kajian Islam membahas tentang keislaman. Selain kajian Islam, kegiatan lain yang mampu membentuk karakter relugius siswa pada dimensi aqidah yaitu kajian kitab kuning yang mengkaji tentang kitab Mabadi’ Al-Fiqhiyyah.

Kitab Mabadi' Al-Fiqhiyyah merupakan kitab fiqih bermadzhab Imam Syafi'i, dan merupakan karangan dari Ustadz Umar Abdul Jabbar yang terbagi menjadi empat jilid atau juz. Kitab ini berisi tentang ilmu hukum agama yang mendukung terhadap pelaksanaan ibadah sehari-hari, misal: shalat, puasa, zakat, haji, dan lain sebagainya. Kitab Mabadi' Al-fiqhiyyah biasa digunakan oleh pesantren atau pelajar di Indonesia, terutama bagi pemula. Kitab ini disusun dengan berpedoman pda kemampuan yang sesuai dengan keadaan alam Indonesia, juga mengingat apa yang menjadi kegemaran dan kekuatan akal pikiran para pelajar. ${ }^{12}$

Berdasarkan pengertian diatas kajian Islam pada kegiatan Dewan Jamaah Mushola di SMK PGRI 2 Kota Kediri memang menanamkan karakter religius pada dimensi aqidah. Hal ini dibuktikan dengan kegiatan kajian Islam dan pengajian kitab kuning yaitu

\footnotetext{
${ }^{11}$ Khoiron Rosyadi, Pendidikan Profetik (Yogyakarta: Pustaka Pelajar, 2004), h.152.

${ }^{12}$ Ustadz Umar Abdul Jabbar, Terjemah Mabadiul Fiqih: Dasar Permulaan Fiqih Jilid ke-1, diterjemahkan oleh : Anas Ali, et. Al, (Surabaya: Slim Nabhan) h.2.
} 
kitab Mabadi’ Al-Fiqhiyyah. Saat kajian ini berlangsung tidak hanya membahas tentang hukum Islam, tetapi juga membahas tentang ketauhidan dan diajarkan tentang aswaja.

\section{Pembentukan Karakter Religius Siswa pada Dimensi Ibadah Melalui Kegiatan Dewan Jamaah Mushola (DJM) di SMK PGRI 2 Kota Kediri.}

Berdasarkan pengamatan yang dilakukan peneliti, pembentukan karakter religius pada dimensi Ibadah sangat erat kaitannya dengan ibadah yang dilakukan sehari-hari yang dilakukan oleh siswa, baik dilingkungan sekolah maupun dirumah. Menurut Mohammad Mustari, dimensi ibadah berisi tentang tata cara melakukan ibadah /penyembahan kepada Tuhan dengan segala rangkaian. Ibadah dapat menimbulkan rasa cinta pada keluhuran. ${ }^{13}$

Sesuai pernyataan diatas kegiatan pada dimensi ibadah adalah shalat berjamaah. Menurut Shidiq Tono shalat adalah ibadah pertama yang diwajibkan dalam Islam pada Nabi Muhammad pada peristiwa isro' mi'roj yang termasuk dalam rukun Islam. Ibadah shalat adalah ibadah yang paling diutamakan, karena ibadah yang paling utama ditanyakan saat di akherat adalah ibadah shalat.

Imam Ahmad Ibnu Hambal menjelaskan bahwa shalat jamaah lebih baik (afdhal) dilakukan karena mengandung hikmah yang sangat besar, dimana didalamnya terdapat semangat persaudaraan (ukwah) dan menambah semangat untuk melaksanakan ibadah, suasana kebersamaan dan keteraturan dibawah pimpinan seorang imam. ${ }^{14}$

Berangkat dari pendapat diatas shalat jamaah merupakan anjuran bagi kaum muslim. Pembentukan karakter religius pada dimensi ibadah dilakukan melalui shalat jamaah yang dilakukan disekolah. Selain shalat berjamaah, adapula beberapa kegiatan yang dapat membentuk karakter religius pada dimensi ibadah yaitu Diba'iyyah, seni baca tulis Al-Quran, dan khotmil Quran yang dilakukan setiap hari jumat setelah pulang sekolah.

\section{Pembentukan Karakter Religius Siswa pada Dimensi Akhlak Melalui Kegiatan Dewan Jamaah Mushola (DJM) di SMK PGRI 2 Kota Kediri.}

Sesuai pengamatan yang dilakukan peneliti terhadap kegiatan yang dilakukan dalam membentuk karakter religius pada dimensi akhlak, yang mana akhlak merupakan

\footnotetext{
${ }^{13}$ Mohamad Mustari, Nilai Karakter Refleksi Untuk Pendidikan (Jakarta: Raja Grafindo Persada, 2014), h.4.

${ }^{14}$ Imam Ahmad Ibnu Hambal, Bentuklah Sholat Anda, terj Umar Hubeis Bey Arifin (Jakarta: Bulan Bintang, 1974), h. 125.
}

Indonesian Journal of Islamic Education Studies (IJIES)

Volume 2, Nomor 1, Juni 2019 
manifestasi dari aqidah (iman), serta ibadah yang terpaut pada sifat dan kebiasaan seseorang sehingga melahirkan akhlak yang menjadi kebiasaan.

Menurut Imam Al-Ghozali akhlak merupakan suatu perangai (watak/tabiat) yang menetap pada jiwa seseorang yang merupakan sumber timbulnya perbuatan-perbuatan tertentu dari diri seseorang secara refleks tanpa dipikirkan atau direncanakan terlebih dahulu. Karakter tumbuh dalam diri seseorang karena adanya pembiasaan dan latihanlatihan sehingga karakter tersebut dapat tertanam kuat pada jiwa seseorang tanpa adanya paksaan. ${ }^{15}$

Bardasarkan pengamatan, kegiatan dalam pembentukan akhlak ini dilakukan melalui metode pembiasaan berakhlak terpuji seperti bersikap tawadhu' baik kepada guru, teman, dan adik kelas serta selalu mengedepankan akhlak dimanapun mereka berada.

Sesuai hal tersebut yang dijelaskan oleh Muhammad Rabbi Muhammad Jauhari yang menyatakan bahwa pembinaan akhlak melalui metode pembiasaan bahwa akhlak terpuji adalah metode yang paling mudah dilakukan tanpa adanya kekersan dan paksaan . metode ini dapat dilakukan dilingkungan keluarga, sekolah dan di masyarakat dengan cara melakukan pembiasaan akhlak seperti tawadhu', bersikap ramah, dan saling memberi salam. ${ }^{16}$

\section{Penutup}

Fenomena dekadensi moral yang tengah terjadi dilingkungan pemerintah dan ditengah-tengah masyarakat serta tindakan kriminalitas, asusila, dan korupsi, menjadi bukti nyata telah terjadi krisis jatidiri dan karakteristik pada bangsa Indonesia. Budi pekerti luhur, sopan santun, dan nilai agama yang dijunjung tinggi dan menjadi budaya masyarakat Indonesia saat ini seakan menjadi terasa asing dan jarang ditemui ditengah masyarakat. Hal ini disebabkan oleh beberapa faktor yang melatarbelakanginya, dan dari sinilah dilakukan pembentukan karakter religius.

Pembentukan karakter religius pada dimensi Aqidah ini melalui kegiatan kajian islam yang materinya membahas tentang hukum-hukum Islam yang dilakukan setiap hari jumat wage, dan kegiatan pengajian kitab kuning yang mengkaji kitab Mabadi' Alfiqhiyyah yang dilaksanakan setiap hari jumat pon. 2012), h.210.

${ }_{15}$ Al-Ghozali, Ihya Ulumuddin jilid 4 terj. Ibnu Ibrahim Ba'adillah (Jakarta: Republika Penerbit, 2006), h.91.

${ }^{16}$ Muhammad Rabbi Muhammad Jauhari, Keistimewaan Akhlak Islam (Bandung: Pustaka Setia, 
Kegiatan pembentukan karakter religius pada dimensi ibadah yaitu melalui kegiatan pembiasaan shalat dhuhur berjamaah. Tujuan shalat berjamaah dilingkungan sekolah yaitu agar siswa dapat menjalankan shalat tepat waktu, dan diharapkan siswa dapat menjalin silahturahmi yang baik antar sesama siswa dan kepada guru. Untuk shalat wajib yang lain dipantau oleh orang tua murid. Dengan adanya kerjasama ini memudahkan guru PAI dalam mengontrol peserta didik yang utamanya dapat membentuk karakter peserta didik pada dimensi ibadah.

Selain shalat dhuhur berjamaah ada beberapa kegiatan lain yang dapat membentuk karakter religius siswa pada dimensi ibadah yaitu diba'iyyah, seni baca Al-Quran, dan khotmil Quran yang rutin dilaksanakan oleh anggota DJM setiap hari jumat setelah jam pulang sekolah dan dibimbing oleh guru PAI.

Pada pembentukan karakter religius pada dimensi akhlak yaitu dengan menggunakan metode pembiasaan berakhlak terpuji. Metode pembiasaan ini dilakukan dengan membiasakan siswa untuk bersikap tawadhu' kepada siapapun dan dimanapun mereka berada. Para siswa dibiasakan untuk memberikan salam dan bersikap ramah kepada guru dan teman dalam setiap aktifitasnya disekolah. Dengan demikian diharapkan metode pembiasaan tersebut dapat membentuk karakter religius siswa pada dimensi akhlak dengan baik.

\section{Daftar Pustaka}

Al-Ghozali, Ihya Ulumuddin jilid 4 terj. Ibnu Ibrahim Ba'adillah, Jakarta: Republika Penerbit, 2012.

Arnani Faiziyah,"'Transformasi Nilai-Nilai Religius Dalam Pembentukan Karakter (Studi Kasus Pada Siswa SMK Arrahmah Purwotengah Papar Kediri)", Jurnal Pendidikan Islam, Vol.7. 1 (Desember 2017).

Deni Damayanti, Panduan Implementasi Pendidikan Karakter di Sekolah, Jogjakarta: Araska, 2014.

Departemen Agama RI, Panduan Kegiatan Ekstrakulikuler Pendidikan Agama Islam, Jakarta: Direktorat Jenderal Kelembagaan Pendidikan Agama Islam, 2005.

Imam Ahmad Ibnu Hambal, Bentuklah Shalat Anda, terj Umar Hubeis Bey Arifin, Jakarta: Bulan Bintang, 1974.

Khoiron Rosyadi, Pendidikan Profetik, Yogyakarta: Pustaka Pelajar, 2004. 
Lisa'diyah Ma'rifataini, "Model Penanaman Nilai-Nilai Karakter Siswa SMA Berbasis Pendidikan Agama”, Jurnal Penelitian Pendidikan Agama dan Keagamaan, Vol 13. 1 (April 2015).

Mohamad Mustari, Nilai Karakter Refleksi Untuk Pendidikan, Jakarta: Raja Grafindo Persada, 2014.

Mohammad Ali Daud, Pendidikan Agama Islam, Jakarta: Raja Grafindo Persada, 1998.

Muchlas Samani dan Hariyanto, Konsep dan Model Pendidikan Karakter, Bandung: PT Remaja Rosdakarya, 2011.

Muhammad Rabbi Muhammad Jauhari, Keistimewaan Akhlak Islam, Bandung: Pustaka Setia, 2006.

Siswanto, "Pendidikan Karakter Berbasis Nilai-Nilai Religius", Jurnal Pendidikan Islam, Vol.8, 1 (Juni 2013).

Tim Penyusun Kamus Pusat Pembinaan dan Pengembangan Bahasa Departemen Pendidikan dan Kebudayaan, Kamus Besar Bahasa Indonesia, Jakarta: Balai Pustaka, 1994.

Ustadz Umar Abdul Jabbar, Terjemah Mabadiul Fiqih: Dasar Permulaan Fiqih Jilid ke1, diterjemahkan oleh : Anas Ali, et. Al, (Surabaya: Slim Nabhan).

Zubaedi, Desain Pendidikan Karakter, Jakarta: Kencana, 2013. 